\title{
Turtle remains (Testudines, Chelonioidea) from the Middle Turonian of northwest Germany
}

\section{Diedrich ${ }^{1} \&$ R. Hirayama ${ }^{2}$}

1 Nansenstr. 8, D-33790 Halle/Westphalia, e-mail: cdiedri@gmx.net

2 Faculty of Information Teikyo Heisei University Uruido, 2289-23 Ichihara, Chiba 290-0193, Japan; e-mail: renhrym@ab.mbn.or.jp

Manuscript received: February 2001; accepted: January 2003

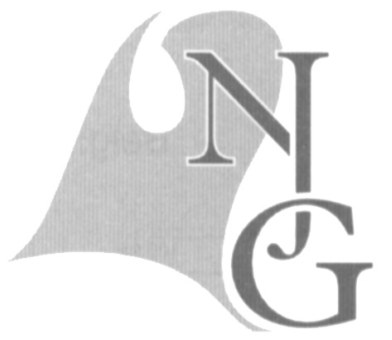

\begin{abstract}
Turtle remains ascribed to the family Cheloniidae (Testudines, Cryptodira, Chelonioidea), collected from the lamarcki zone (Middle Turonian) at Wüllen (NW Germany) are described. The material consists of a right humerus, a scapula, a complete costalia, and costalia fragments of a single individual with the humerus indicating a primitive cheloniid of the 'toxochelyid grade'. The present material, as well as previously recorded chelonioid humeri from the Cenomanian and Turonian of Germany illustrate a progressive diversification of chelonioids during the early Late Cretaceous.
\end{abstract}

Keywords: Humeri, Turtles, Cheloniidae, Upper Cretaceous, Europe

\section{Introduction}

The turtle remains described in the present paper were collected in the 1970 s by Mr. A. Duckstein (Münster), from the Middle Turonian as formerly exposed at the Hollekamp quarry (topographical map, $1: 25000$ sheet 3907 Ottenstein, co-ordinates $\mathrm{R}$ 256755 and $\mathrm{H} 577120$, Fig. 1), which is now flooded and actually a freshwater lake. This important fossil site is very well known in North Germany especially for its rich echinid faunas (Ernst et al. 1998).

Turtle remains are quite rare in the Cenomanian/ Turonian of Europe and of special interest. Specimens described here are compared with previously recovered material, in particular humeri. Described have been squamate remains of Coniosaurus crassidens Owen 1850 (Diedrich, 1997, 2001), Dolichosaurus longicollis Owen 1850 (Diedrich, 1999a, 2001) and a cheloniid remain (Diedrich, 1999b).

The material described here is housed in the Geol-
ogisch-Paläontologische Institut und Museum der Westfälischen Wilhelms-Universität Münster.

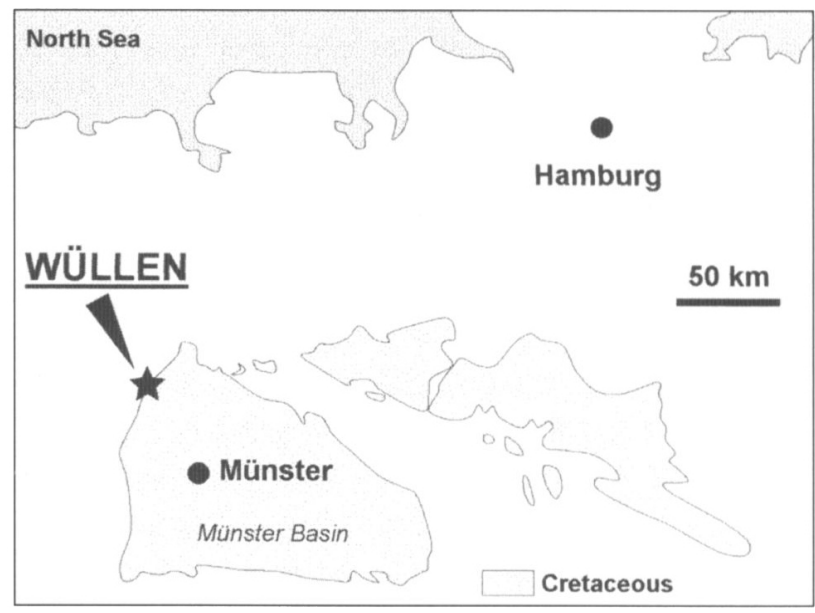

Fig. 1. The location of Wüllen within the Münster Basin of Northwest Germany. 


\section{Geological setting}

Cretaceous deposits are widely distributed in North Germany. The Late Cretaceous Turonian sediments occurs at the margin of the Münster Basin and consist at the Wüllen quarry of slightly cemented white chalks.

The section formerly exposed at the Hollekamp quarry at Wüllen (Fig. 2) ranged from the uppermost Upper Cenomanian, dated by a rare huge Puzosia dibleyi Spath var. spinosus in the $M$. geslinianum am- monite zone,) to the Lower Coniacian is developed as Rotpläner Member swell facies (compare Diedrich, 2001, Ernst et al. 1998). The section published by Ernst (1978) is here extended (Fig. 2). The turtle remains were collected from the Middle Turonian lamarcki inoceramid zone. This zone is highly fossiliferous, having yielded echinoids, ammonites and other macroinvertebrates (Ernst, 1967, 1978; Löscher, 1910, Ernst et al., 1998).

The environment of the cheloniid finding must have been the slope facies in the Münster Cretaceous

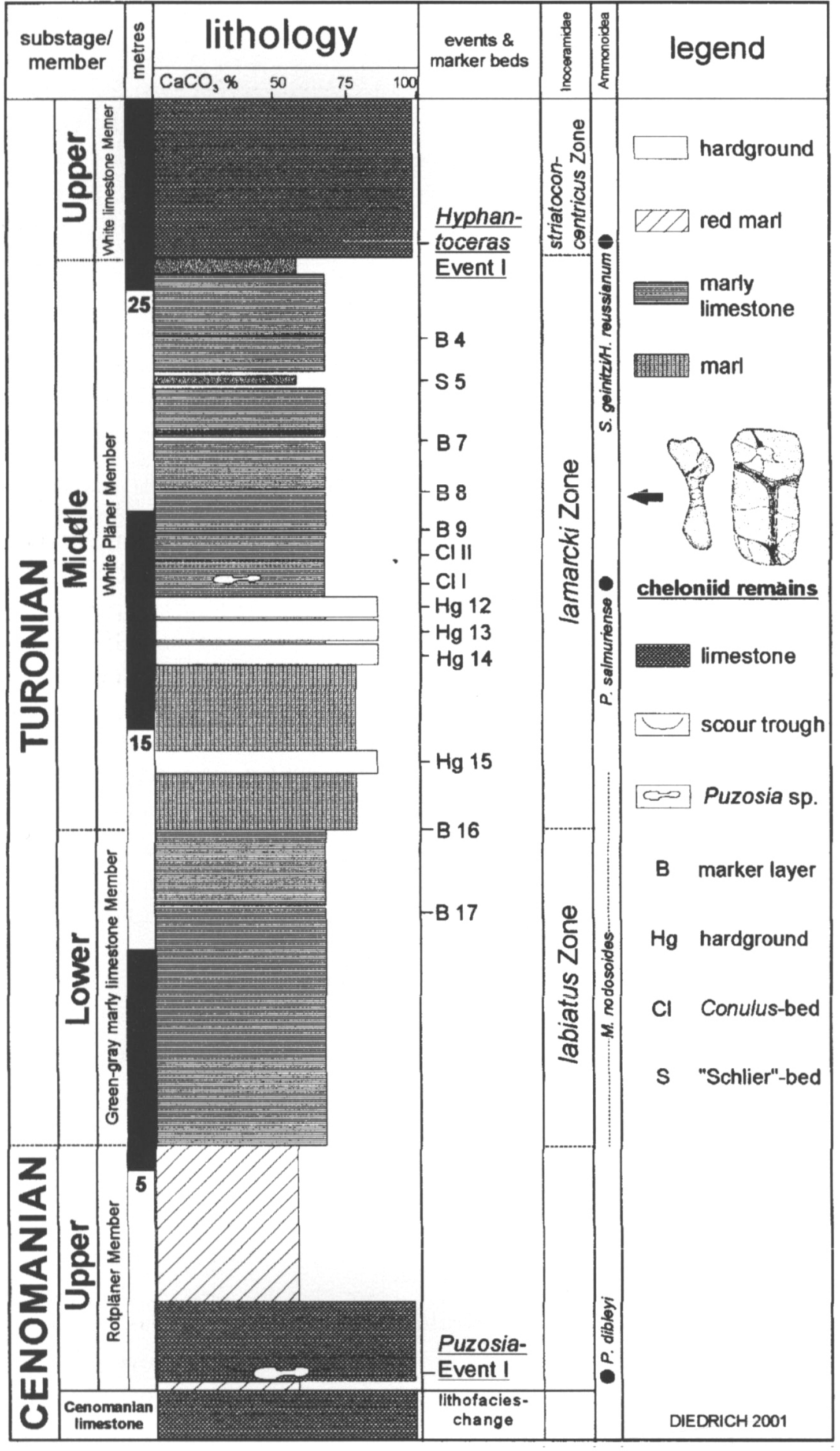

Fig. 2. Stratigraphical provenance of the turtle material described from the Wüllen. 
Basin (compare Ernst, 1967). Löscher (1910) and Ernst (e.g. 1978) published many macroinvertebrates. The echinid genera Conulus, Discoides, Echinogalerus, Echinocorys, Sternotaxis, Infulaster, Micraster and Hemiaster are often accumulated in scour troughs or the body chambers of the huge ammonites Lewesiceras peramplum or Puzosia sp. The most abundant irregular echinid is Conulus.

\section{Systematic palaeontology}

Order Testudines Linné 1758

Superfamily Chelonioidea Agassiz 1857

Family Cheloniidae Gray 1825

Genus and species indeterminate

Fig. 3.1-3.3

\section{Material}

A right humerus, one costalia, a fragmentary scapula, and eleven costal fragments, all assumed to have belonged to a single individual, Geologisch-Paläontologisches Institut und Museum der Westfälischen Wilhelms-Universität Münster, No. A.3A-32.

\section{Description}

As preserved the right humerus (Fig. 3.1 ) is $83 \mathrm{~mm}$ long, the maximum width proximally being $39 \mathrm{~mm}$, the maximal distal brightness $21 \mathrm{~mm}$, and the smallest width medially of the corpus femura $12 \mathrm{~mm}$ maximum width distally. Slightly flatened and only 7-10 $\mathrm{mm}$ thick, although the caput humeri and distal portion appear slightly worn. The medial process is poorly developed, and along the proximal edge not distinctly separated form the caput humeri. The caput humeri appears to lack the shoulder developed, and is proportionally much smaller than in most chelonioids. The angle between the axis of the caput humeri and the humeral shaft is about $135^{\circ}$. The lateral process is small and located very proximally, directly connected to the caput humeri by a bony ridge. The scar for the $M$. latissimus dorsi \& $M$. teres major is small and located anteriorly of the humeral axis. The scar for the $M$. coracobrachialis brevis is also small and located just distally the caput humeri. The humeral shaft is slender, lacking a pronounced distal expansion. The ectepicondylar foramen is missing, possibly due to post-mortem erosion.

The fragmentary right scapula (Fig. 3.3), as preserved $56 \mathrm{~mm}$ long, lacks the distal portions of both scapular prong and acromion. The angle between the scapular prong and the acromion is nearly $90^{\circ}$.

A costalia (Fig. 3.2), the left second or fourth plate, is of $50 \mathrm{~mm}$ length and $106 \mathrm{~mm}$ in width, and shows well-defined scute sulci of vertebral and costal scutes. This suggests a relatively wide vertebral scute, equalling the costal in width. The size of this costal indicates the carapace to have been of about $500 \mathrm{~mm}$ in total length.

\section{Discussion}

An overview of the Testudines was given by Mlynarski (1976). Important monographies and papers of Upper Cretaceous Chelonioids of North and South America were published by Case (1897), Hay (1908), Zangerl (1953a, b) and Zangerl \& Sloan (1960). Recently Hirayama (1992, 1995, 1997, 1998), Hirayama \& Chitoku (1996), and Hirayama \& Hikida (1998) compared Cretaceous sea turtles worldwide.

Cenomanian/Turonian marine sea turtles of Europe are rare and were Fig.d for the first time from Southeast England by Mantell (1841) as Emys benstedi. New finds from England were described by Owen (1842), who established a new geus Cimochelys benstedi. After some years Geinitz (1849) mentioned one humerus of a chelonioid in central Germany, described later together with a second humerus, both as Chelone carusiana Geinitz 1875 (Geinitz, 1872-75) (now Protostegidae gen. and sp. indet.). Owen (1850, 1851) worked on English Cretaceous chelonioids and described a skull of Chelone pulchriceps ( $=$ Rhinochelys pulchriceps). Meyer (1856) collected a carapace with articulated femur of a new turtle from the Greensand (Cenomanian/Turonian) of Kelheim (South Germany) first believed to be an chelonioid and named Helochelis Danubia Meyer (= Helochelys danubianus Von Meyer 1855, see Mlynarski 1976), but Helochelis is one of the few terrestrial pleurodiran cretaceous turtles of Europe, closeley related to the genus Tretosternon (cf. Hirayama et al. 2000). Seeley (1869) created the new genus Rhinochelys for a skull of the Cambridge Greensand (Upper Albian to Lower Cenomanian), and referred Owen's material (1850, 1851) to this genus. A carapace fragment of the cheloniid Cimochelys benstedi( Owen 1850) was Fig.d by Fritsch (1878). The fragment was stored in the Weissenberg Member (Turonian) of Bohemia. Lydekker (1889a, b) described isolated skulls of Rhinochelys as $R$. cantabrigiensis Lydekker, $R$. macrorhina Lydekker $1889, R$. elegans Lydekker 1889, $R$. brachyrhina Lydekker 1889, R. jessoni Lydekker 1889, and $R$. pulchriceps (Owen 1850) from the Cambridge Greensand (Upper Albian to Lower Cenomanian) of England. In the same year Woodward (1889) mentioned carapace fragments of Cimochelys. In France Moret (1935) collected skulls of $R$. amaberti Moret 1935 from the 'Vra- 
conien' (Albian). Collins (1970) revised this genus Rhinochelys, only $R$. pulchriceps, $R$. elegans and $R$. cantabrigiensis of the Cambridge Greensand (UpperAlbian to Upper-Cenomanian) being valid species. Hirayama (1997) considered the latter two, as well as $R$. amaberti and Cimochelys benstedi as synonyms of $R$. pulchriceps. Milner (1987) Fig.d a Rhinochelys-skull from Southeast England (Middle to Upper Cenomanian). The described Cimochelys benstedi shell remains of the Middle Cenomanian to Turonian represent juvenile protostegids and may belong to the skulls of Rhinochelys (Collins, 1970; Milner, 1987).

Humeri of representatives of the superfamily Chelonioidea are quite diverse, reflecting their specialised locomotion in marine environments (Walker, 1971; Hirayama, 1992). Their morphology was summarised by Hirayama (1992) there we follow his terminology (also Fig.d by Diedrich 1999b) and systematics. For recent reviews of chelonioid systematics based on cladistics, especially of Cretaceous taxa, reference is made to Hirayama $(1995,1997,1998)$, Hirayama \& Chitoku (1996), and Hooks (1998).

The caput humeri of the described new humerus from Wüllen (Fig. 3.1) appears to lack the shoulder developed in most chelonioids except Toxochelys and Osteopygis (Hirayama, 1992), and is proportionally much smaller than in most chelonioids, including Ctenochelys (= Lophochelys of Hirayama, 1992), Allopleuron, Cenozoic cheloniids, most protostegids, as well as dermochelyids (Hirayama, 1992). The angle between the axis of the caput humeri and the humeral shaft is about $135^{\circ}$ such as in Rhinochelys, but neither

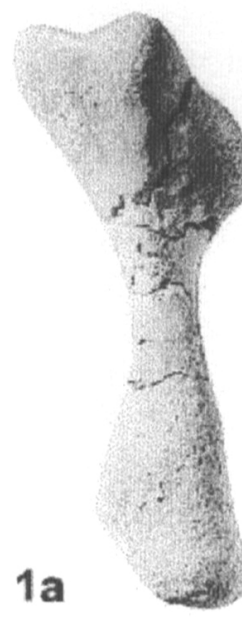

1b

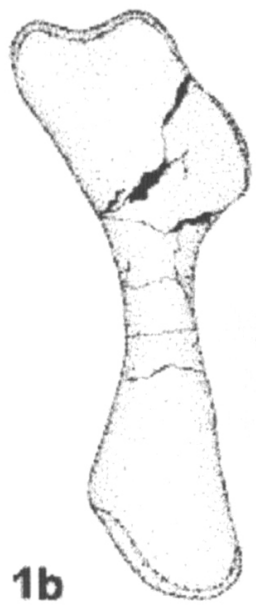

1c
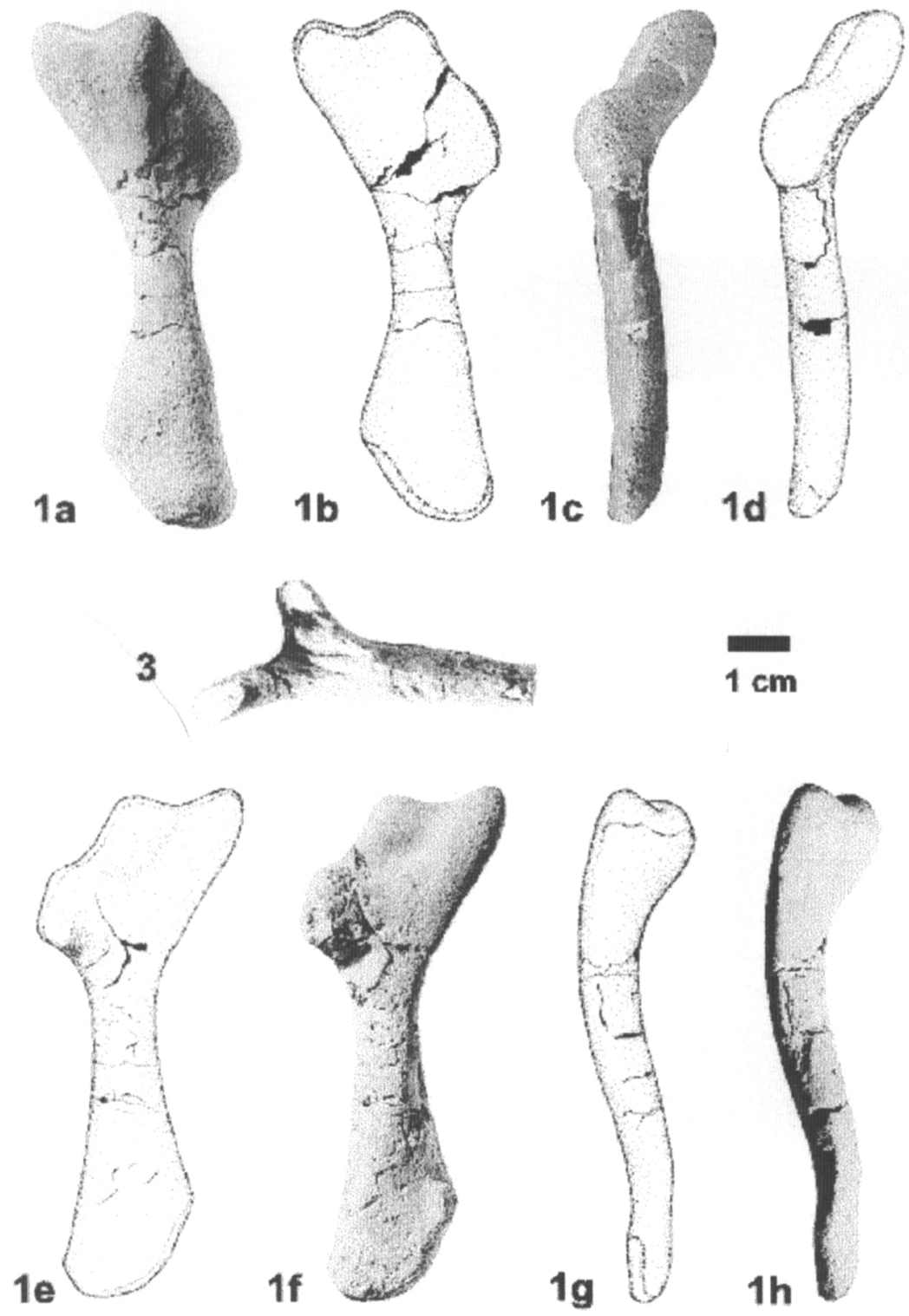

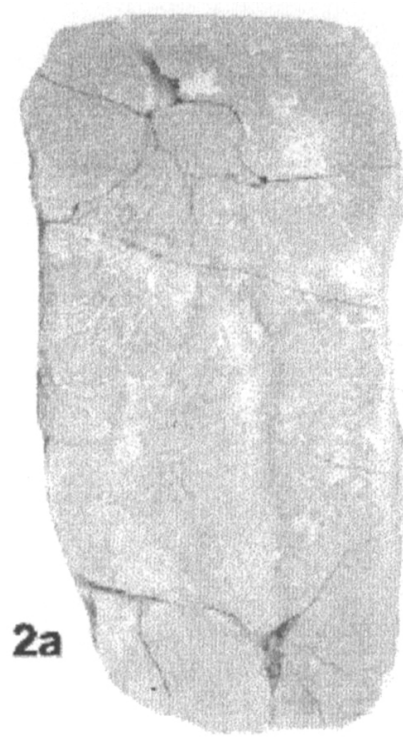

$1 \mathrm{~cm}$
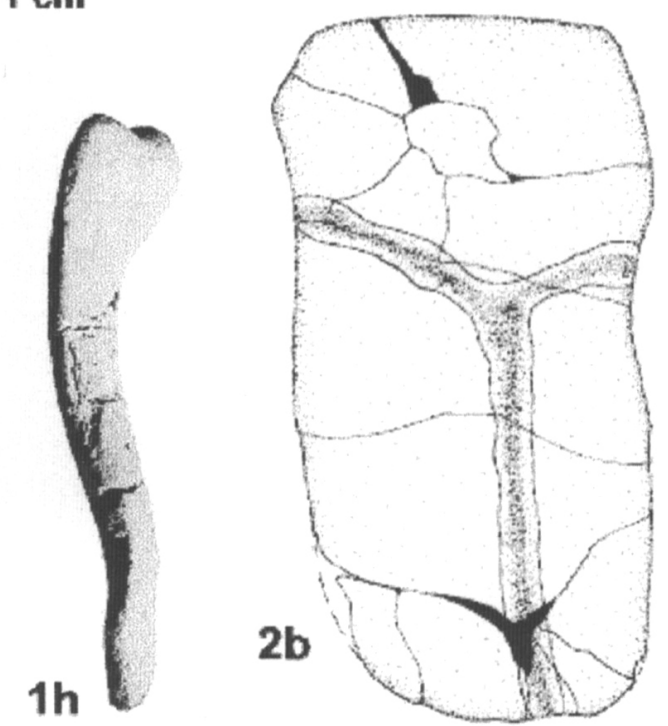

Fig. 3. Chelonioid from the Middle Turonian (lamarcki zone) of Wüllen, 1. Right humerus, a-b. dorsal, c-d. cranial, e-f. ventral, g-h. caudal; 2a-b. Costalia, dorsal with costal scutes, 3. Right scapula, ventral. Geologisch-Paläontologisches Museum der Westfalischen Wilhelms-Universität Münster, collection No. A.3A-32. 
right angle as in Osteopygis, nor nearly straight as in Dermochelys. The lateral process is small and located very proximally, directly connected to the caput humeri by a bony ridge as in primitive cheloniids such as Toxochelys and Osteopygis. The scar for the M. latissimus dorsi \& $M$. teres major is small and located anteriorly of the humeral axis as in primitive cheloniids e.g. Osteopygis and protostegids e.g. Rhinochelys. The humeral shaft is very slender, lacking a pronounced distal expansion unlike advanced cheloniids e.g. Allopleuron, protostegids e.g. Protostega, and Dermochelys. The present specimen represents a chelonioid of advanced humeral features such as the distal position of the lateral process and the absence of a caput humeri shoulder not seen in freshwater or terrestrial turtles. The shoulder is definitely present in Toxochelys and Osteopygis, suggesting important differences in phylogenetic and functional meanings in chelonoid evolution. However, other features, such as the poor development of a medial process and the very distal position of the scar for $M$. latissimus dorsi \& M. teres major, suggest it to be a rather primitive cheloniid of the 'toxochelyid grade' of Hirayama (1992), which includes Toxochelys, Ctenochelys and Osteopygis. Isolated humeri from the Gault and Cambridge Greensand (Middle-Late Albian) of England, referred to an unnamed cheloniid, are most similar to our specimen in having a relatively small caput humeri and in lacking of the shoulder (Hirayama, 1992; Figs 4A-C). The ratio between the humerus length and the carapace length estimated to have been about $500 \mathrm{~mm}$ long (is about $1: 5$ to $1: 6$ ), suggest that its paddles must have been very small, as in primitive chelonioids such as Toxochelys and Santanachelys gaffneyi Hirayama 1998 (Hirayama, 1995, 1997, 1998).

Previous records of Cretaceous chelonioid humeri from Germany include specimen described as Rhinochelys (?) carusiana from the Turonian of central Germany (Fig. 4.1, 4.3). These specimens illustrated by Geinitz (1872-75) and the one from the Middle Cenomanian recorded by Diedrich (1999b, Fig. 4.2) appear to represent primitive protostegids in view of the development of the lateral process being limited to the anterior region of the humeral shaft. The medial process of those humeri is developed more proximally than in primitive cheloniids of the 'toxochelyid grade'. However, placement in Rhinochelys is doubtful, because humeri from England referred to Rhinochelys (e.g. Fig. 4.4), are more slender and have much smaller caput humeri than the humerus of Halle/Westph. (Hirayama, 1992, Fig. 6G-I). Rhinochelys humeri show the protostegid derived features such as the anterior faced lateral process and a median concavity of the lateral process, which are absent in the new humerus of Wüllen (Fig. 4.5). The proportions of a humerus figured by Geinitz (1872-75; pl. 46, Fig. 1) are more close to those of Desmatochelys from the Cenomanian-Turonian of North America and Japan (Hirayama, 1992, 1995, 1997; Elliott et al., 1997).

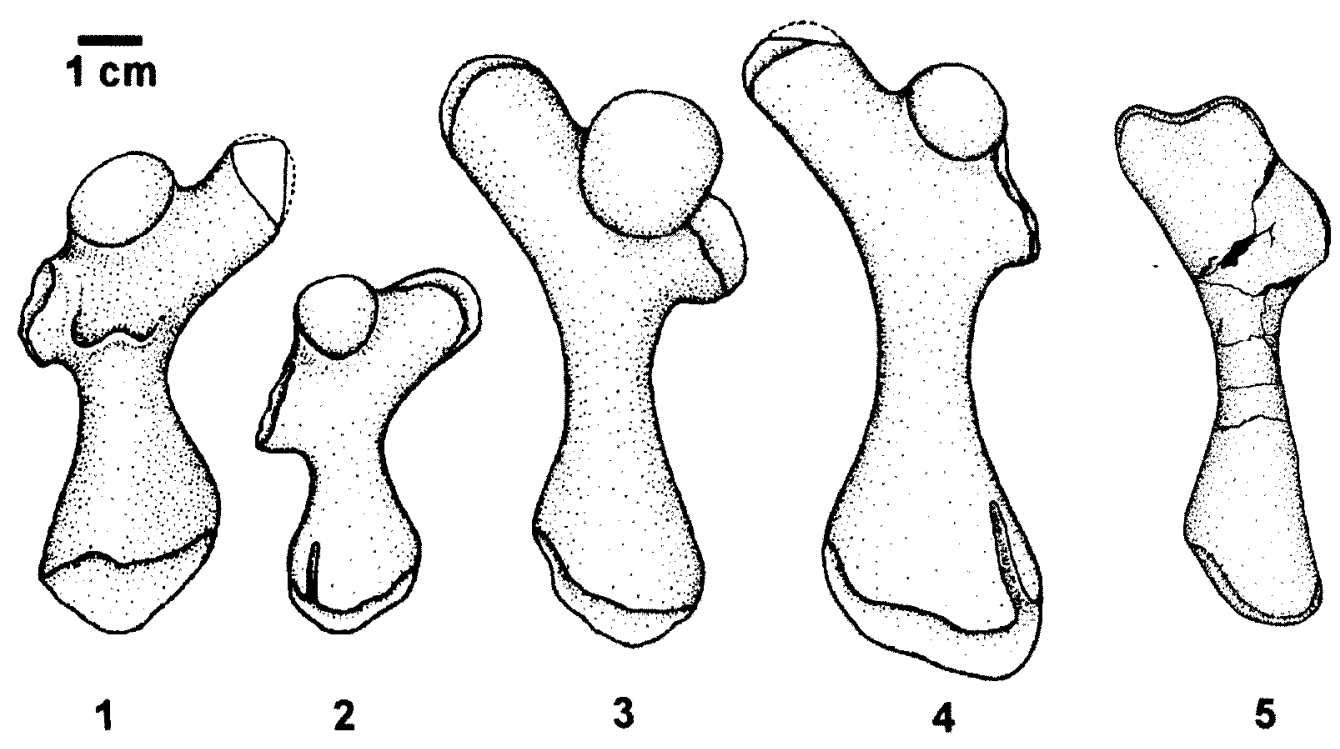

Fig. 4. Comparison of various European chelonioid humeri. 1: Protostegidae, left humerus, Turonian of Bohemia (after Geinitz, 1872-75), Museum Dresden, without No., 2: Protostegidae, left humerus, Middle Cenomanian of Halle/Westphalia (after Diedrich, 1999b), ErdZeitCenter Borgholzhausen, collection No. Ascheloh-mc-1, 3: Protostegidae, right humerus, Upper Albian/Lower Cenomanian of Cambridge (Rhinochelys cantabrigiense (Lydekker) after Lydekker, 1889a, b), British Museum of Natural History, collection No. 35175, 4: Protostegidae, right humerus, Turonian of Bohemia (after Geinitz, 1872-75), Paläontologisches Museum der Universität Freiberg, without No., 5: Protostegidae, right humerus, Middle Turonian of Wüllen, Geologisch-Paläontologisches Museum der Westfalischen Wilhelms-Universität Münster, collection No. A.3A-32. 
The humeri described by Geinitz (1872-75) are best considered a Protostegidae gen. and sp. indet. The isolated left humerus from the Cenomanian of Halle/Westph. was originally referred to Rhinochelys (?) cf. carusiana by Diedrich (1999b). Upon re-examination it appears more likely that this belongs to more advanced protostegids such as Chelosphrargis, rather than to Rhinochelys, since the specimen shows a definite protostegid feature, e.g. the anteriorly faced lateral process with a median concavity absent in Santanachelys, the most primitive protostegid from the Albian of Brazil (Hirayama, 1998). The lateral process is well developed, the distal portion of which is nearly located at the centre of the humerus as in fairly advanced protostegids such as Chelosphargis, Protostega, and Archelon (Hirayama, 1992, fig. 6M-U). The scar for the $M$. latissimus dorsi \& $M$. teres major is positioned anteriorly of the axis of the humeral shaft unlike in the above-mentioned protostegids where the scar is located at the centre of the shaft. In this feature, it more closely resembles 'Protostega' anglica Lydekker 1889, a poorly known protostegid, based on isolated humeri from the Albian-Cenomanian of England (compare Hirayama, 1992, fig. 6J-L). However, in the Halle/Westph. specimen the lateral process is more massive than in 'Protostega' anglica, and the humeral shaft is wider and more flattened in the latter. Thus, the humerus from Halle/Westph. is best considered a Protostegidae gen. and sp. indet.

The angle between the scapular prong and the acromion of the Wüllen material is nearly $90^{\circ}$ as in some cheloniids such as extinct Toxochelys, Osteopygis, Tasbakka, Puppigerus, extant Caretta and Lepidochelys (Zangerl, 1953; Moody, 1974; Nessov, 1987; Zangerl et al., 1988). The costalia (Fig. 3.2) and costal fragments of the Wüllen specimen do not contribute anything to the assignment among chelonioids because of lacking well comparable material. The presence of scute sulci of the costal plate just indicates a generalized primitive pattern of the chelonioids and corresponds to the humeral identification. Only humeral morphology can be used for taxonomic analysis in this case.

Cenomanian and Turonian chelonioids are still poorly known worldwide and comparable by their humeri (Fig. 4). Thus, the protostegid humerus from the mid-Cenomian described by Diedrich (1999b) and protostegid reported material of the mid-Turonian of the open marine facies here seem making a first contribution to our knowledge of morphological diversifications in Cenomanian-Turonian chelonioids. These finds strongly suggest that chelonioid sea turtles of the early Late Cretaceous had possibly reached a diversity comparable to Latest Cretaceous ones.
However, some protostegid chelonioids from the Cenomanian/Turonian of Europe have been described, and here a new primitive cheloniid can be added. The diversification of the Chelonioidea had begun during the early Late Cretaceous. In post-Turonian, marine turtles were recorded from the Coniacian to Campanian of North America, the Maastrichtian of the Netherlands, and Belgium, the middle to upper Yezo Supergroup (Turonian to Maastrichtian) of northern Japan (Zangerl, 1953a, b, 1960; Nicholls \& Russell, 1990; Hirayama, 1995, 1997; Hirayama \& Chitoku, 1996; Hirayama \& Hikida, 1998; Mulder et al., 1998), and the Maastrichtian of France (Tong, et al., 1998) with much more complete skeletons.

\section{Acknowledgements}

We thank A. Duckstein (Münster, Germany), for donating the specimen, Prof. Dr. K. Oekentorp, and Dr. M. Bertling (Geologisch-Paläontologisches Museum der Westfälischen Wilhelms-Universität Münster, Germany) for stratigraphical information and permission to publish the specimen. We are also grateful to M. Brinkmann, M. Samson and J. Gores for preparing casts of some cheloniid humeri. Finally we thank three unknown referees for a critical review of the first manuscript.

\section{References}

Case, E.C., 1897. On the osteology and relationships of Protostega. Journal of Morphology 14: 21-60.

Collins, J.I., 1970. The chelonian Rhinochelys Seeley from the Upper Cretaceous of England and France. Palaeontology 13 (3): 355-378.

Diedrich, C., 1997. Ein Dentale von Coniosaurus crassidens Owen (Varanoidea) aus dem Ober-Cenoman von Halle/Westf. (NWDeutschland). Geologie und Paläontologie in Westfalen 47: 4351.

Diedrich, C., 1999a. Erster Nachweis von Dolichosaurus longicollis Owen (Varanoidea) aus dem Ober-Cenoman von Halle/Westf. (NW-Deutschland). Neues Jahrbuch für Geologie und Paläontologie Monatshefte 1999 (6): 372-384.

Diedrich, C., 1999b. Ein Humerus der Chelonide Rhinochelis (?) cf. carusiana (Geinitz 1872-75) aus dem Mittel-Cenoman von Halle/Westf. (NW-Deutschland). Neues Jahrbuch für Geologie und Paläontologie Monatshefte 1999 (9): 541-550.

Diedrich, C., 2001. Die Großammoniten-Kolktaphozönosen des Puzosia-Event I (Ober-Cenoman) von Halle/Westf. (NWDeutschland). Münstersche Forschungen zur Geologie und Paläontologie 90: 1-208.

Elliott, D.K., Irvy, G.V. \& Hutchison, J.H., 1997. Desmatochelys lowi, a marine turtle from the Upper Cretaceous. In: Callaway, J.M. \& Nicholls, E.L., (eds.): Ancient Marine Reptiles, Academic Press, San Diego: 243-258.

Ernst, G., 1967. Über Fossilnester in Pachydiscus-Gehäusen und das Lagenvorkommen von Echiniden in der Oberkreide NWDeutschlands. Paläontologische Zeitschrift 41 (3/4): 211-229. 
Ernst, G., 1978. Wüllen bei Ahaus - Kalkbruch des Kalkwerkes Hollekamp. In: Kemper, E., Ernst, G. \& Thiermann (eds.): Symposium Deutsche Kreide Münster i. W. 1978, Exkursion A: A II, Münster: 10-20.

Ernst, G., Seibertz, E. \& Wood, C.J., 1998. D 2.4 CenomanianTuronian of Wüllen near Ahaus. In: Mutterlose, J., Bornemann, A., Rauer, S., Spaeth, C. \& Wood, C.J. (eds.): Key localities of the northwest European Cretaceous. Bochumer geologische und geotechnische Arbeiten, 48: 157-164

Fritsch, A., 1878. Die Reptilien und Fische der böhmischen Kreideformation. The author, Praha: $44 \mathrm{pp}$.

Geinitz, H.B., 1849. Das Quadersandsteingebirge oder Kreidegebirge in Deutschland. Craz \& Gerlach Verl., Freiberg: 290 pp.

Geinitz, H.B., 1872-75. Das Elbthalgebirge in Sachsen. Zweiter Theil. Der mittlere und obere Quader. Palaeontographica 20 (2): $7+245$ pp.

Hay, O.P., 1908. The fossil turtles of North America. Publications of the Carnegie Institute, 75: $568 \mathrm{pp}$.

Hirayama, R, 1992. Humeral morphology of chelonioid sea-turtles; its functional analysis and phylogenetic implications. Bulletin of the Hobetsu Museum 8: 17-57 (in Japanese with English Abstract)

Hirayama, R., 1995. Phylogenetic systematics of chelonioid sea turtles. The Island Arc 1994, 3 (4): 270-284.

Hirayama, R., 1997. Distribution and diversity of Cretaceous chelonioids. In: Callaway, J.M. \& Nicholls, E.L. (eds): Ancient Marine Reptiles, Academic Press, San Diego: 225-241.

Hirayama, R., 1998. Oldest known sea turtle. Nature 392: $705-$ 708.

Hirayama, R. \& Chitoku, T., 1996. Family Dermochelyidae (Superfamily Chelonioidea) from the Upper Cretaceous of North Japan. Transactions and Proceedings of the Palaeontological Society of Japan New Serie 184: 597-622.

Hirayama, R. \& Hikida, Y., 1998. Mesodermochelys (Testudines, Chelonioidea, Dermochelyidae) from the Late Cretaceous of Nakagawa-cho, Hokkaido, North Japan. Bulletin of the Nakagawa Museum of Natural History 1: 69-76.

Hooks, G.E.I., 1998. Systematic revision of the Protostegidae, with a revision of Calcarichelys gemma Zangerl, 1953. Journal of Vertebrate Paleontology 18: 85-98.

Löscher, W., 1910. Die Westfälischen Galeritenschichten mit besonderer Berücksichtigung ihrer Seeigelfauna. Neues Jahrbuch für Mineralogie, Geologie und Paläontologie BeilagenBand 30: 269-312.

Lydekker, R., 1889a. Catalogue of the fossil Reptilia and Amphibia in the British Museum (Natural History). III. Order Chelonia. London: $28+309$ pp.

Lydekker, R., 1889b. On remains of Eocene and Mesozoic Chelonia and a tooth of (?) Ornithopsis. Quarterly Journal of the Geological Society London 45: 227-246.

Mantell, G., 1841. On the fossil remains of turtles, discoverd in the Chalk Formation of South-East England. Philosophical Transactions of the Royal Society London 131: 153-158.

Meyer, H.v., 1856. Helochelis Danubia, aus dem Grünsande von Kelheim in Bayern. Palaeontographica 4 (3): 96-105.

Milner, A.C., 1987. Reptiles. In: Owen, E. \& Smith, A.B. (eds.) Fossils of the Chalk. Palaeontological Assotiation London. Field Guides to Fossils 2: 266-280.

Moret, L., 1935. Rhinochelys amaberti, nouvelle espèce de tourtue marine du Vraconien de la Fauge, près du Villard-de-Lans (Isère). Bulletin de la Societé géologique Francaise (5), V (1): 605-619.

Mlynarski, M., 1976. Testudines. In: Kuhn, O. (ed.): Handbuch der Palaeoherpetologie 7: $130 \mathrm{pp}$.

Moody, R.T.J., 1974. The taxonomy and morphology of Puppigerus camperi (Gray), an Eocene sea-turtle from Northern Europe. Bulletin of the British Museum (Natural History) Geology 25 (2): 155-186.

Mulder, E.W.A., Jagt, J.W.M., Kuypers, M.M.M., Peeters, H.H.G. \& Rompen, P., 1998. Preliminary observations on the stratigraphic distribution of Late Cretaceous marine and terrestrial reptiles from the Maastrichtian type area (SE Netherlands, NE Belgium). Oryctos 1: 55-64.

Nessov, L.A., 1987. The Paleogene sea turtles of Southern Kasakhstan and the phylogenetic relationhips between Toxochelyidae and the Cheloniidae. Paleontological Journal 21: 7384 (translated from Paleontologicheskii Zhurnal 1987 (4): 7687.

Nicholls, E.L. \& Russell, A.P., 1990. Paleobiogeography of the Cretaceous Western Interior Seaway of North America: the vertebrate evidence. Palaeogeography, Palaeoclimatology, Palaeoecology 79: 149-169.

Owen, R., 1842. Description of the remains of a chelonian reptile from the chalk. Trans. Geological Society (2) 6:412.

Owen, R., 1850. Description of the fossil reptiles of the Chalk formations $I n$ : Dixon, F. (ed.): The geology and fossils of the Tertiary and Cretaceous formations of Sussex, Longman, Brown, Green and Longman, London: 378-405.

Owen, R., 1851. A monograph on the fossil Reptilia of the Cretaceous formations. Palaeontological Society Monographs 5 (1851-64): 1-118.

Seeley, H.G., 1869. Index to the fossil remains of Aves, Ornithosauria, and Reptilia from the Secondary System of Strata arranged in the Woodwardian Museum of the University of Cambridge, Cambridge: $23+143$ pp

Tong, H., Gaffney, E.S. \& Buffetaut, E., 1998. Foxemys, a new sidenecked turtle (Bothremydidae: Palomedusoides) from the Late Cretaceous of France. American Museum Novitatis 3251: 1-19.

Woodward, A.S., 1889. A synopsis of the vertebrate fossils of the English chalk. Procedings of the Geological Association 10: 273 338.

Walker, W.E., Jr., 1971. Swimming in sea turtles of the family Cheloniidae. Copeia 1971: 229-233.

Zangerl, L.R., 1953a. The vertebrate fauna of the Selma Formation of Alabama. Part III, The turtles of the family Protostegidae. Fieldiana Geology 3 (3): 59-133.

Zangerl, L.R., 1953b. The vertebrate fauna of the Selma Formation of Alabama. Part IV, The turtles of the family Toxochelidae. Fieldiana Geology Memoirs 3 (4): 137-277.

Zangerl, L.R. \& Sloan, R.E., 1960. A new specimen of Desmatochelis lowi Williston, a primitive chelonid sea-turtle from the Cretaceous of South Dakota. Fieldiana Geology 14 (2): 7-40.

Zangerl, R., 1960. The vertebrate fauna of the Selma Formation of Alabama. Part 5. An advanced cheloniid sea turtle. Fieldiana Geology Memoirs 3: 281-312.

Zangerl, R., Hendrickson, L.P. \& Hendrickson, J.R., 1988. A redescription of the Australian flat back sea turtle, Natator depressus. Bishop Museum Bulletin of Zoology 1: 1-69. 